\title{
The Public Space of "Jogja Fashion Week Carnival" and Cosplay Clothing in Yogyakarta
}

\author{
Deni Setiawan $^{\bowtie 1}$, Timbul Haryono ${ }^{2}$, Agus Burhan ${ }^{2}$ \\ ${ }^{1}$ Programme of Performing and Fine Arts, Graduate School, Gadjah Mada University. \\ ${ }^{2}$ PGSD Depaterment, Faculty of Education, Semarang State University.
}

Permalink/DOI: http://dx.doi.org/10.15294/komunitas.v6i2.3303

Received : July 2014; Accepted: August 2014; Published: September 2014

\begin{abstract}
The concept of an ideal public space does not just focus on the interests of a particular group or community, but rather focus on the space of social activities that represent each audience or spectator in that society. Arts and cultural activities are part of it; although the concept of public space is still abstract to represent every social individual. However, the presence of public space has created a mediation space for all forms of communication. Mediation space is considered as a crucial feature, not only as a promotional sphere but also as a place to exchange and communicate all forms of ideology, art, and culture. Art activities such as Jogja Fashion Week Carnival and Cosplay clothing performance in public spaces provide opportunities for communities or individuals, to make this activity as a public performance and part of public art. Public art tends to be creative, free, and sometimes not accompanied by a theoretical perspective, as other arts are. Art activities in public spaces which are part of the social and cultural activities are essentially standing on the ideology that have been set up for a particular interest. The interest is disseminated using mass media and advertisment. Audience or public art connoisseur in public spaces should be more intelligent and critical to accept all kinds of art activities and performances. Therefore the performance will have a balanced communication.
\end{abstract}

\begin{abstract}
Abstrak
Konsep ruang publik yang ideal tidak saja berbicara kepentingan golongan atau komunitas tertentu, tetapi lebih fokus pada wadah aktivitas sosial yang mewakili setiap pendatang atau penonton. Termasuk didalamnya adalah aktivitas seni dan budaya, walaupun konsep ruang publik masih dapat dikatakan abstrak untuk mewakili setiap individu sosial. Akan tetapi dengan adanya ruang publik telah menciptakan ruang mediasi bagi segala macam bentuk komunikasi. Ruang mediasi ini dipandang penting, tidak saja dijadikan ranah promosi, lebih mendalam adalah untuk bertukar dan tempat komunikasi segala macam bentuk ideologi, kesenian, dan kebudayaan. Aktivitas seni semacam Jogja Fashion Week Carnival dan pagelaran pakaian cosplay pada ruang publik memberikan kesempatan bagi komunitas atau individu, untuk menjadikan aktivitas ini sebagai tontonan dan bagian seni publik. Seni publik ini tentu saja lebih cenderung lebih kreatif, bebas, dan terkadang tidak diiringi dengan perspektif teoretis, seperti yang dilakukan seni lainnya. Aktivitas seni pada ruang publik, merupakan bagian dari aktivitas sosial dan budaya, hakikatnya berdiri pada ideologi yang telah diatur untuk satu kepentingan, yang disebarluaskan menggunakan media massa dan iklan. Penonton atau masyarakat penikmat seni pada ruang publik, harus lebih cerdas dan kritis untuk menerima segala macam bentuk sajian aktivitas seni, sehingga sajian tersebut memiliki komunikasi yang seimbang.
\end{abstract}

Keywords: public space; audience; JFWC; cosplay; art activities

How to Cite: Setiawan, D., Haryono, T., \& Burhan, A. 2015. The Public Space of "Jogja Fashion Week Carnival" and Cosplay Clothing in Yogyakarta. Jurnal Komunitas, 6(2):237-245. doi:http://dx.doi.org/10.15294/ komunitas.v6i2.3303

(C) 2014 Semarang State University. All rights reserved 


\section{INTRODUCTION}

A public space is a interaction place of all kinds of social activities, cultural exchange, as well as gathering places. Tony Thwaites states that culture is a group of social practices where the meaning is being produced, circulated, exchanged, so it is related to other practices (economics, laws, governance, education, etc.) (Broto W. Sulistyo, 2012). According to Jurgen Habermas, a public space is a place where citizens are able to discuss about their social relationships. Therefore, it is an institution to interact with different things (in Ristiana Kadarsih, 2008. Jurnal Dakwah). In Roger Scurton's idea (1984), a public space can be stated as a location which is designed as modest as possible, has a big access to the environment, and is a place for people to interact. As a place, a public space can be used as a tool to achieve a purpose, deal, and include the communication among some interests. Social activities happening in the public space are not only for one group interest, but also for some other parties as well.

A good management for public space will not only have a good influence for art development and existence, but also will have an important influence for safety, economics, politics, social, and cultural stability. As a means for people to do their activity related to art and increase their creativity, a public space is the final purpose in creating an art work. In other words, in a public space, an art creator is challenged to survive from some complicated connection of promoting their self-existence to the non-artist circle. Creating carnival costumes for Jogja Fashion Week Carnival (JFWC) is actually not a matter of making beautiful and interesting clothes to show from the unused materials. It also cannot be said as simple imitation when a person or a cosplayer community create Cosplay costumes which they use animation as their main idea. There are some ideas to share and various implicit meanings in every created costume, including JFWC costumes and Cosplay costumes.

According to some philosophers, a space is a physical reality which cannot be influenced by materials on the inside or by how that materials are understood (Dani Cavallaro. 2001:307). Jurgen Habermas explains that a public space is a media to communicate information and views. The view should be understood as an idea, by using a certain form of art, that would be communicated to other people. This idea cannot be justified directly as positive and negative affairs, but we need to pay attention to the main question like; what, how, and where this idea can be communicated. A public space is related to not only physical entities, like: public facilities, meeting halls, fields, malls, supermarkets, stalls and salon, but also a space where communication can run well. Basically, public spaces not only have physical form like some examples, but also can have non-physical form, such as: mass media, both printed and electronic. So, a public space is a space to interact each other among some intensions.

A public space offers possibility for some cultural resources to exchange and blend. JFWC event and Cosplay costumes exhibition which are managed by some communities, organizations and local government of Yogyakarta, are not only contextualized for hobbies and interests. For example in JFWC, this event is made to support the clothing industries which almost falls down due to imported products. Not only promoting batik as their signature product, they also make carnival costumes by using unused materials which are processed to become some art costumes. Just like Cosplay costumes, creators from Yogyakarta create Indonesian traditional and cultural themes. Finally, art costumes have been active in promoting Javanese mythology and legendary figures in the society. This identity is very important, not only as a mark, but also as an effort for self-identity. Castell (2004: 6) states that everybody must have had name, language, and culture with several specifications which are used to differ himself to others. Identity is a source of experience and self-meaning. By identity, every actor gives certain identity to his social attributes $(\mathrm{Pu}-$ jiriani, 2013).

JFWC event and Cosplay clothes exhibition cannot stand alone without any help 
and participation from mass media, ads, and spectators. This mutual relationship grows to be a deal, which can run unwell if the good connection between all components does not exist. Mass media and ads are under machines and technologies' control to produce power optimally. Machine technology such as television, shows there is an emotional connection which includes activities of art and the spectators. The activity of art and television consist of some components which are interrelated as well as its role of so do the role of spectators.

\section{PUBLIC SPACE THEORY}

The use of the term "public space" has been stated by K. Lynchby who states that the public space consists of the district, edge, nodes, path, landmark which became navigation instruments in the city (Lynch,1960). AS Hikam (1999:201) shares his idea that public space as public sphere means as the area where society and citizens have full access to their public activities (Robi Cahyadi Kurniawan. 2011). The public space which appeared around $18^{\text {th }}$ century was pictured as a bridge which connected individual needs and people in the demanded family, also social and public intention (Hendrikus T. Gedeona. 2008). Stephen Carr (1992:19) categorizes three main qualities of a public space, those are:

1. responsive, these spaces are designed and managed by considering the users' intention.

2.democratic, the rights of public space users are kept well, the users can express their idea freely in that public space, but still have certain limits because in using the public spaces there are some tolerance values among the public space users to be considered.

3.meaningful, including the emotional connection between the space with the user's life (in Juarni Anita, et al: 2012).

According to Carmona (2003:111) a public space consists of some part, those are:

1. External public space, is a public space which the exterior could be accessed by all people, for example: city park, alun- alun (town square), pedestrian, and other outdoor spaces.

2. Internal public space, a public space as a public facility which is managed by the government and can be accessed by the people freely without any limit, such as: post office, police station, hospital, and other public service offices.

3. External and internal "quasi" public spa$c e$, as a public space for public facility which is managed by a private party and limited or has certain rules to obey, like: mall, discotheque, restaurant etc.

Some roads which are used to hold JFWC and Cosplay clothes exhibition belong to the category of external public space, where everybody can access and watch the exhibition of both kinds of clothing types. In some other cases, Cosplay clothes which are exhibited with special performance, is categorized as an external and internal "quasi" public space because it belongs to a private committee. Therefore, sometime people who want to watch the exhibition must pay.

A public place can be also divided based on its function, such as:

1. Positive space, a public space can be used for positive activities and usually managed by the government. The examples of this kind of public space are: natural space/semi natural space, public space and outdoor public space.

2. Negative space is a public space which cannot be used for public activities optimally because it has certain function which is not comfortable and safe for social activities and it is not managed well. The examples are: movement space, service room, and abandoned rooms which are left due to the planning process.

3.Ambiguous space, is a space used for transformation activities from people's main activities, for a living room in a store, café, religious place, recreation room.

4. Private space, is an outdoor space owned privately by people, for example: front yard and room inside a building (Carmona, et al: 2008:62).

Referring to the management and responsibility of the maintenance, roads all over Yogyakarta belong to the government, 
so they can be categorized as a public space with positive space function.

A public space in a housing complex will run well if it has these components:

1. Comfort, is the most important requirement for public spaces' success. The duration of people staying in the public space can be a standard of how comfortable a public space is. In this case, the comfort of a public space is influenced by: environmental comfort which is a protection from the influence of the nature like the sun light, wind; physical comfort shown by the availability of supporting facilities like seats; and social and psychological comfort.

2. Relaxation, is an activity which is related to psychological comfort. A relaxing condition can be achieved if our body and mind are healthy and happy. The condition can be created by recalling natural components such as plants/trees, water located separated from the noise of vehicles around.

3. Passive engagement, the activity is influenced by the condition of its surroundings. Passive engagement can be done by sitting down or standing up while watching the activities in their surroundings or enjoying the scenery like park, fountain, statue or other arts.

4. Active engagement, a public space is successful if it can organize physical activities/interaction among the society (friends, family or strangers) well.

5. Discovery, is a process of managing a public space so that there will various and enjoyable activities. (in Juarni Anita, et al: 2012).

\section{PUBLIC SPACES IN YOGYAKARTA}

According to George Junus Aditjondro's note, Yogyakarta is not a city of million bicycles, but it has become a city of million motorcycles. The happening phenomenon of motorcycle ownerships has some effects for sidewalks which are used as an outdoor public space. The huge amount of motorcycle on the road makes motorcycle riders expand to the outdoor public space, sidewalk, and green space in the city park. Ex- cept the bad effect of pollution, the safety for pedestrian will be also threatened because the sidewalk has been taken by the motorcycle riders (Matajendela Magazine, Vol. VII No. 1/2012). Some people even call Yogyakarta as a would-be metropolitan city as Jakarta which is so crowded and there is always traffic jam.

The limited public space is related to the transformation of Yogyakarta as a metropolitan city. According to Punto Wijayanto, metropolitan area itself is technically defined according to the huge concentration of people there, with the unity of social economy, characterizing city's activities, and having more than one million people. Although the number of people in Yogyakarta city has not reached one million people, but it has structurally built a metropolitan area because of agglomeration ${ }^{1}$ in Bantul and Sleman Regencies. This symptom even had been recognized since 1980s via Yogya Urban Development Program (Wijayanto, 2012).

According to Adishakti, the development and growth of Yogyakarta consist of four phases. First, the developing phase of the city, which is marked by Giyanti Pact in 1755, resulting the Sultanate of Yogyakarta. The development of Yogyakarta runs fast, in form of building Keraton and some supporting facilities, such as: fortresses, mosques, and markets. The city space is filled up with housing named by the profession of the people that is abdi dalem, or the group of the troops, like: Patehan, Gamelan, Patangpuluhan, Bugisan, and Mantrijeron. There also ssome area for foreigners, for example Pecinan (China Town) for Chinese people who live around the market.

Second, the growth of this city is influenced by the perspective of Dutch and English about space. In the north part of Keraton Yogyakarta, Vrederburg fortress or Loji Besar was built in 1776-1778. The Dutch Residence which is famous as Loji Kecil, is

\footnotetext{
1 Alliance or association of two or more activity centers; the place for grouping various activities in one location or area, it can be industrial region, housing area, trade center. Etc. (which can develop through administration limit of each region so it creates a new region which is planned imperfectly).
} 
supported with various facilities, such as: schools and churches. During the British occupation, Loji Kebon (1924), which is located in front of Vredeburg fortress or currently named as Gedung Agung, the Residency Hall was built. Lempuyangan Railway Station was built and finished in 1872, Railway Station of Yogyakarta (Tugu) as public railway station started to operate on may $2^{\text {nd }}$ 1887. Gradually, Some buildings were built around Vredeburg fortress, like: Beringharjo Market, de Javasche Bank in 1879, insurance office of Nill Mastchappij, Posten Telegraf office. In 1899 Petronella Zienkenhuis (Bethesda Hospital) was built. There was a new housing area in 1920 as Kotabaru, Jetis Region. An eye hospital dr.Yap was built in 1922 by Sultan Hamengku Buwono VIII. Islamic University of Indonesia was built in 1947, Gajah Mada Institute in 1946 (finally became Gajah Mada University on December $19^{\text {th }}$ 1949).

Third, UGM Balairung was built. In 1960, Islamic State Sunan Kalijaga Institute was moved from the building in Simanjuntak street (Islamic State High School 1 of Yogyakarta) to Adisucipto street. That area, including Mrican, Babarsari, became downtown area. Fourth, the growth of Yogyakarta as City Agglomeration of Yogyakarta (APY) is the effect of housing areas, hotels, and modern markets. There was a huge conversion for agricultural land in Sleman and Bantul Regencies. The development of hotels and tourism objects cannot be separated from the development of tourism policy which is arranged by the head office since 1980s, as the income from non-oil and gas sectors (Matajendela Magazine, Vol. VII no. 1/2012)

From the previous four phases, we can see that the growth of Yogyakarta is fast, including how the public spaces decrease time by time for public interest. The decrease of public space perhaps is one of some negative effects from Yogyakarta's popularity with many labels ${ }^{2}$. Therefore, Yogyakarta invitesmany people to come together. The arrival and crowd of many new people not only

2 City of Cultures, City of Students, City of Education, Tourism City, The Most Comfortable City, children Safe City, Creative City, Mural City. have positive effects for economy, tourism, industry but also have crucial effect for the existence of public spaces. The images of Yogyakarta give chances to the government to try managing the city space optimally. It is possible that one day the public spaces will extinct and will be replaced by housing complex, hotels, modern markets, and other buildings if they are not managed precisely and carefully from now. Public spaces are still important for holding events which support the dynamics of culture, education, and interaction among people.

Under Regional Regulations No. 6 1994, about the General Plan for Urban Planning of Yogyakarta in the period of 1994-2004, there was a plan for arranging and managing the public spaces. Regional Regulations of Yogyakarta No. 22010 is also about Urban Planning of Yogyakarta Year of 2010-2029. These regional regulations do not directly regulate various people activities in urban planning. There is an unsynchronized relations between the use of space as it is expected and in the reality. The urban planning has not advocated the social dynamics happening in the real life yet. This planning system has not been able to solve the gap problem between the planners and other parties, like the government, people, and private parties. Something that has been built by the government, such as: XT Square, Gembira Loka Zoo, Jogja Expo center, and Giwangan Bus Station, actually has not been optimized yet (Matajendela Magazine, Vol. VII No. 1/2012).

\section{THE GOVERNMENT AND PRIVATIZ- ING PUBLIC SPACES}

Talking about privatizing public spaces is like directly pointing the ownership of the spaces to the government. It is reasonable in order to avoid the ownership of the public spaces to the other parties that will commercialize them, although sometimes the government themselves do the same thing. Managing public spaces in Yogyakarta cannot be separated from the ownership of the space itself. For example, Vredeburg Fortress, Malioboro Area, Taman Budaya Yograkarta Hall are places managed by the 
government. As they develop, privatization happens to the other public facilities, which ends up limiting public spaces for the people. The ownership of public spaces by certain institutions or corporations which have capital for commercialization will privatize the public places and eventually become a place to take advantages. Therefore, the expectation of a public space as a one stop area for people's activities is impossible to achieve.

Privatizing public spaces done by certain group is a big threat for people. A space where they can express their idea freely, interact with other people, and play around in Yogyakarta will be limited. Discussing the concept of public space as public facility for people's need to interact, the examples such as the city park or non-commercial public places will be decreased in Yogyakarta. When a public space is used massively, if there is carnival, of course it will disturb other public space users' comfort.

Public space privatization is an effort from the government which surely will limit people to access the public space. The government should optimize the function and management of public spaces optimally, not to pursue financial profit by conducting business from it. A public space is able to create certain characteristics of people who live in a particular city. The unavailability or lack maintenance public will create nonconformist maverick, individualist, and asocial society. The members of society will not be able to interact with other. Public spaces must be neutral, not on somebody's side and not limit other groups' intention.

People's social interaction in some social and art activities in certain public spaces actually has an important role to create a stable condition within society. The availability of public spaces for holding JFWC, Cosplay clothing exhibition, and other art activities, as a part of the government's duty to serve the people, definitely encourages positive effects too for the government's interest. Social and art activities can be used as the main asset to invite tourists, buyers, investors, and spectators which are not separated from the process of promoting local cultures (Javanese legends and mythologies) to other people.

The art activities (JFWC and Cosplay clothing) cannot be said as an event which ignores other people's interest. The event is indeed a part of some efforts to entertain people and give public service. ${ }^{3}$ Holding and managing good public spaces will make people comfortable, even it can give positive effect for people's economic development. In Yogyakarta, it is still possible to provide good public space facilities if they are well-managed and professional for people's interest.

\section{Art, Mass Media and Public Spaces Ac- tivities}

Bruce Robbins defines a public space as a place where interaction and conversation among people exist, a place where idea and thought intersect. Human's interaction is a part of people's life, as in mass media. On the other hand, mass media plays a central role in public spaces. In fact, only in mass media, most of people's population can come together to exchange their idea (Alan Mckee.2005: 5-6). Art activity as an important source of mass media can be a barometer to measure the good management in a public space. The bigger and more maximum a public space in mass media, the more it shows its support toward art activities. Art activities, mass media and public spaces, are like the relationship between artists with the spectators, without any strings attached, the art itself will die.

Television as an electronic mass media is not only able to create social trends but also to fulfill every people's interest for the need of information, entertainment and other interests. Television has a power to create, produce, and manipulate the history. W.T. Anderson refers this event as an artificial event because it is never spontaneous, but it is well-planned with certain purpose to serve to the spectators massively (Marcel Danesi. 2004: 246). Television is such

3 Besides JFWC, there are some other events which use public spaces, such as: Tionghoa Yogyakarta Cultural Week which has been held for nine times, Jogja Java Carnival, Yogyakarta's Birthday, Ruwahan Apeman Cultural Festival. 
social texts which not only passes through private boundary but also can create a deal to influence the ideology and someone's perspective. As an information tool for any kinds of activity, including making art, television will be more effective to be used for promotion, including the activity of JFWC and Cosplay clothing exhibition.

Every mass media has the ability and function to 'interact' with the readers or spectators,; it is possible to exchange information from one to another about their own intention. Media is a tool which is not limited to the room and time but also to save and serve any kind of information and sometimes being able to serve some communicating intention. A public space in mass media can be used as a discussion room, a room to exchange point of view to accept, process, and finish the situation of social condition. Besides serving as a static room, a public space in media can give chances to many people to take part in preserving the culture and tradition nationally. Regarding to public intention, JFWC event belongs to all people who love art, culture and tradition heritage, because the chosen theme is Javanese situation and condition in the form of Javanese legend or mythology.

The structure growth and change of social life in Yogyakarta is related to art activities, which surely gets the support from mass media. The up-to-date political and cultural issues for mass media become theme line to some activities of creating arts for creators. The regional government's policy is a crucial matter to encourage the continuity of public spaces and art activities. Creating the event of JFWC and Cosplay clothing exhibition as least show that the existence of art activity. Mass media as a massive public space must play the role to provide the information about art activities in the private spaces so there will be good bonding on some parties which are actually give advantages each other.

\section{The Role of Spectators, Art Activities and Advertisement in Public Spaces}

If we look at the theory of a space code, there are 3 different kinds of space, those are: pri- vate space, public space, and sacred space. Private space regulates the way to interact in personal area, while sacred space manages the interaction in the place which contains the components of metaphysic, mystic or spiritual qualities. Public space is built for the place to attract some people together who want to get entertainment, recreation, celebration or other purposes (Marcel Danesi. 2004: 226-227). For the same basic purpose, public spaces are able to get people's attention to interact each other. It can be entertainment, casual conversation, playing together, discussion, or having vacation to pursue happiness.

Spectators come in shows or other art activities to get entertainment, to interact each other, to exchange experience, and to give information. JFWC event and Cosplay clothing exhibition held by the committee in Yogyakarta is an interesting show for people to watch. Moreover for those who love fashion and clothing. Simplification of interaction from some parties is a communication, which is to exchange information (Marcel Danesi. 2004: 276). The spectators are not only consumers but also people who have rights to get quality shows.

Spectators can be partners of interaction to communicate each other to receive evaluations which is needed to measure and improve the quality of an art activity or an art form better. The spectators should be treated as an active producer, regarding to the context that they reading the texts, both constructional and routine in daily life. According to spectators' characteristics, they consist of two kinds, active spectators and passive spectators (Chris Barker. 2004: 1-2). Passive spectators are the spectators who get influenced easily by media, while active spectators' are those who are more active in making decisions of how to use media. The theory of mass society tends to use passive concept, although not all passive spectators' theories are legally called as mass society theory. On the other hand, people tend to use active theory.

Another communication media as an additional tool of producer is advertisement. The advertisement will facilitate the 
producers to impress and ask people to do something, according to the purpose of the advertisement. If JFWC event and Cosplay clothing exhibition do not use the advertisement, the event will not attract many people. An advertisement has propaganda inside, although it is not exactly as it seems. Harold D. Laswell in Nurudin, states that propaganda is a technique to influence people's activities by manipulating its representatives. In addition, it is not more than an opinion control which is done by using meaningful symbols through stories or other forms which can be used in social communication (Nurudin. 2001: 10). Actually the role propaganda is so important. The propaganda is used not only to impress people to get more spectators to come to JFWC event and Cosplay clothing exhibition but also to underline the main purpose of the event. By good propaganda technique, the theme which is wrapped in traditional form can be delivered optimally.

Advertising has three main categories, those are: advertising for consumers (to promote products), advertising for trading (trading publication), and advertising for politic-social interest (advertising views). Advertising is related to trading and marketing (Marcel Danesi. 2004: 257). In JFWC event and Cosplay clothing exhibition, we can meet those three factors. First, JFWC event and Cosplay clothing exhibition is held to promote new designs made by designers which have selling value to help the growth of clothing industry. Second, this event is held commercially although the promoted clothes need special treatment and time but the promotion component for trading refers to a name of certain designer or an owner institution of the exhibited clothing designs. Third, this event has another purpose to promote certain view, idea, and other values (advice, guidance) from the Javanese legends and mythology in some clothing designs of JFWC and Cosplay clothing exhibition.

\section{CONCLUSION}

Public spaces as a part of general society are used to promote clothing products in JFWC event and Cosplay clothing exhibition. The presence of spectators in public spaces to see and enjoy art activities is the evidence of the successful advertisement in attracting people. On the other hand, the cooperation from some parties is needed to create public spaces which are not taking sides to privatization and commercialization of certain groups. A public space is a place for some interactions of culture and ideology, trading transaction, exchanging idea, and entertainment sources for society. A public space should not take side to certain social groups, should not to be commercialized, and should be free from any attitude of underestimating other groups. The existence of art activity, like JFWC event and Cosplay clothing exhibition in public spaces, has structures serving as an instrument for promotion, trading, and giving information about local traditions. Public spaces management, both the government and private owner, have obligation to serve spectators/ people with interesting, high-quality, and educational shows and not breaking other groups' ethics. Art activities, creator, media, advertisement, and spectators are important parts to create positive public spaces. Management with a good system will produce amusing public spaces for society in Yogyakarta

\section{REFERENCES}

Aditjondro, G. J. 2012. Ketika Yogyakarta Bukan Lagi Kota Sejuta Sepeda. Majalah Matajendela. 7(1):4-7.

Anita, J., et. al. 2012. Kajian Terhadap Ruang Publik Sebagai Sarana Interaksi Warga di Kampung Muararajeun Lama, Bandung. Jurnal Online Institut Teknologi Nasional. Teknik Arsitektur Itenas. 1(1):1-12.

Barker, C. 2004. The SAGE Dictionary of Cultural Studies. London: Sage Publications.

Broto, W.S. 2012. Jurnal IPTEK. 16(1):9-16.

Carmona, et al. 2003. Public Places-Urban Spaces, The Dimension of Urban Design. Architectural Press.

Carmona, et al. 2008. Public Space: The Management Dimension. Routledge. New York, USA: Taylor \& Francis Group.

Cavallaro, D. 2001. Teori Kritis dan Teori Budaya. Yogyakarta: Penerbit Niagara. 
Danesi, M. 2004. Messages, Signs, and Meanings: A Basic Textbook in Semiotics and Communication Theory. Toronto: Canadian Scholars' Press Inc.

Gedeona, H.T. 20o8. Peranan Ruang Publik dalam KehidupanMasyarakat Multikultural. Jurnal Ilmu Administrasi. 5(1): 33-43.

Kadarsih, R. 2008. Demokrasi dalam Ruang Publik: Sebuah Pemikiran Ulang untuk Media Massa di Indonesia. Jurnal Dakwah. 9(1):1-12.

Kurniawan, R.C. 2011. Ruang Publik PascaEraReformasi. Jurnal Ilmiah Administrasi Publik dan Pembangunan. 2(2): 366-371.

Lynch, K. 1960.The Image of City. Cambridge: MIT
Press.

Mckee, A. 2005. The Public Sphere: An Introduction. Cambridge. New York: Cambridge University Press.

Nurudin. 2001. Komunikasi Propaganda. Bandung: Penerbit PT. Rosdakarya.

Pujiriyani, D.W. 2013. Re-Imajinasi Ke-Indonesia-an dalam Konteks 'Network Society'. Jurnal Komunitas. 5(2): 151-161.

Wijayanto, P. 2012. Merencanakan Kota Yogyakarta: Yogyakarta adalah Sebuah Metropolitan. Majalah Matajendela. 7(1): 8-15. 